\title{
Corporate Governance and Intellectual Capital: Impact on the Financial Performance of State-Owned Enterprises in Indonesia
}

\author{
Husnah Nur Laela Ermaya, Ayunita Ajengtiyas Saputri Mashuri \\ Universitas Pembangunan Nasional (UPN) Veteran Jakarta, Indonesia \\ Email: husnah_ermaya@upnvj.ac.id, ayunita.ajeng@upnvj.ac.id
}

\begin{tabular}{|c|c|}
\hline ARTICLE INFO & ABSTRACT \\
\hline $\begin{array}{l}\text { Received } \\
\text { 02 September } 2021 \\
\text { Revision } \\
10 \text { September } 2021 \\
\text { Approved } \\
15 \text { September } 2021 \\
\text { Keywords: } \\
\text { Financial Performance; } \\
\text { Independent } \\
\text { Commissioner; } \\
\text { Audit Committee; } \\
\text { Institutional } \\
\text { Ownership; } \\
\text { Intellectual Capital }\end{array}$ & $\begin{array}{l}\text { Using company size and leverage as control variables, this study aims to } \\
\text { evaluate the influence of institutional ownership, an independent board } \\
\text { of commissioners, an audit committee, and intellectual capital on } \\
\text { financial performance. The population in this study is all state-owned } \\
\text { companies registered with the Ministry of SOEs with a period of } \\
\text { observation for } 4 \text { years, namely in } 2016-2019 \text {. Purposive sampling was } \\
\text { used in this study to collect samples, and a total of } 164 \text { samples were } \\
\text { collected. The data analysis methods utilized in this study include } \\
\text { descriptive statistical tests, classic assumption tests, and hypothesis } \\
\text { testing utilizing multiple regression analysis by SPSS } 25 \text { version. } \\
\text { According to the findings of this study, institutional ownership and } \\
\text { intellectual capital have a substantial beneficial influence on financial } \\
\text { performance, whereas the independent commissioner has a large } \\
\text { negative effect on financial performance and the audit committee has } \\
\text { no effect on financial performance. }\end{array}$ \\
\hline
\end{tabular}

\section{INTRODUCTION}

The last few years many of the problems that arise regarding the financial performance of state-owned enterprises in Indonesia. This of course makes people become less trusting of performance produced by the company. As is the case in the year 2019 two Commissioners of Garuda Indonesia refused to sign the statement of financial year 2018 because of the discovery of the transactions that should not be known as income by PT Garuda Indonesia. Commissioner of PT Garuda Indonesia is confident that the management should undertake the Management of the Revenues to meet the interests of the management itself. Besides the problem occurred in Garuda Indonesia, there are still many similar cases that experienced by other objects. Such as the case of Pertamina, which the state injured by 586 billion. Pertamina acquisition (investment Nonrutin) in the form of the purchase of some assets (interest in participating/ IP) owned oil company Ltd in blocks of BMG Australia, based on the Agreement on 27 May 2009. Without a warrant, the Director of the President and the board of directors approved the block acceptance of BMG. The case of the fictitious insurance fund occur in the PT. Jasindo conducted by the director to perform the manipulation of the commission agent in procuring insurance on the Oil and gas BP, cases of bribery and corruption committed by the Director of the Krakatau stell as well as the company of his soul that failed to pay, this, of course,

\footnotetext{
How To Cite:

Ermaya, H. N. L., \& Mashuri, A. A. S. (2021) Corporate Governance and Intellectual Capital: Impact on the Financial Performance of State-Owned Enterprises in Indonesia. Jurnal of Social Science. 2(5). https://doi.org/10.46799/jss.v2i5.194

E-Issn: 2721-5202

Published By: Ridwan Institut
} 
demonstrates that there is still a lack of supervision and effective governance in the company's implementation.

A vast number of studies have demonstrated that the presence of institutional ownership in a firm improves the efficiency with which company assets are used, thus is expected that the monitoring of management decisions (Januarti, 2009). Institutional investor's roles may be described in three ways, that is active monitoring, passive monitoring, and backing with managers to exploit smaller shareholders (Elyasiani \& Jia, 2010). According to (Lin \& Fu, 2017), institutional investors can actively and passively supervise management performance. Because of their superior management skills and significant resources, institutional investors should be able to supervise and monitor the manager, decrease information asymmetries, reduce agency issues, and maximize shareholder value through active monitoring. Furthermore, by exercising their ownership rights, these institutional investors may put pressure on management to enhance corporate governance.

Alternatively, (Lin \& Fu, 2017) explain that the institutional investors, according to the passive monitoring perspective, merely act as passive monitors, trading shares for speculative short-term trading profits based on informational advantages, or to fulfill idiosyncratic portfolio needs, rather than managing them. In the third scenario, certain institutional investors work with management to expropriate the dispersed small stockholders (Elyasiani \& Jia, 2010).

Institutional investors serve as an effective monitoring tool for a corporation's minority shareholders, decreasing agency costs and allowing firms to achieve a higher rate of return than the market. In addition, due to their knowledge and understanding of the financial market, institutional investors are more efficient monitors at lower costs than individual investors, and their greater financial stake and longer time horizon allows them to earn better profits. Because of effective corporate governance mechanisms, firms with a large number of institutional investors are more likely to be shareholder-oriented (Malik et al., 2021). The company's value and performance will improve with appropriate management oversight. Therefore, the first hypothesis is developed as follows:

$\mathrm{H}_{1}$ : Institutional ownership has a significant influence towards financial performance.

The board of commissioners, as the company's competent authority, is jointly responsible for overseeing the board of directors and making recommendations to guarantee the company's excellent corporate governance (KNKG, 2006). Member of the commissioner board who are independent are those who do not have any financial, managerial, equity, or familial ties with the other commissioners, directors or controlling shareholders, or any other relationship that might compromise their capacity to act independently (Noorizkie \& Siti, 2013). To guarantee that the monitoring system functions properly and in compliance with existing rules and regulations, the number of Independent Commissioners should be appropriate. It is recommended that one of the independent commissioners has accounting or financial experience (KNKG, 2006).

The existence of independent directors is a mechanism that is intended to perform surveillance and managerial inefficiency due to conflicts of interest between controlling and minority shareholders. The larger the number of Independent Commissioners, the greater the amount of scrutiny and pressure on better management, which pushes management to be more transparent in reporting the company's risks (Zulfikar et al., 2017). One of the most important duties of independent directors is to keep track of the company's performance and operations. An effective monitoring process within the company might help to reduce agency issues. As a result, the firm should choose independent directors who can provide adequate supervision in the areas of governance, internal control, and risk management (Fuzi et al., 2016). Therefore, the second hypothesis is developed as follows: 
$\mathrm{H}_{2}$ : Independent commissioner has a significant influence towards financial performance.

The Audit Committee of Indonesia (APLI) defines the audit committee as a committee that works professionally and independently to oversee the company's financial reporting, risk management, auditing, and corporate governance implementation. The proportion of audit committee members is intended to increase compliance with mandated disclosure. When the audit committee is large, the ability to protect and regulate the accounting and finance processes via enhanced openness extends the control and supervisory functions over the accounting and financial processes (Ojeka et al., 2014).

(Ashari \& Krismiaji, 2020) also stated that The vast quantity of human resources available in the labor market, the amount of pay, and other laws may all have an impact on the demand for audit committee members. These circumstances may necessitate the use of larger number of audit committee to have a significant impact on the firm's financial performance. By doing corporate governance, then the value added of a company can be improved to produce the company's performance is better, and one that can be improved is the intellectual capital. Therefore, the third hypothesis is developed as follows:

$\mathrm{H}_{3}$ : Audit committee has a significant influence towards financial performance.

In Indonesia, the concept of intellectual capital (IC) begins to emerge, particularly with the introduction of SFAS No. 19 (revised 2000) about intangible assets. Although it is not expressly designated as IC, it has received considerable attention. According to SFAS No. 19, intangible assets are non-monetary assets that may be identified but do not have a physical form, as well as assets held to be used to develop or provide products or services, leased to others, or used for administrative purposes (IAI, 2012).

The implementation of intellectual capital in Indonesia is still very less. There are many firms that are still unaware of the value of putting intellectual capital in their daily operation. This is evidenced by the company's reluctance to devote more attention to intellectual capital. In reality, intellectual capital plays an important part in the attempt to improve the company's worth. The company's performance might be enhanced by increasing its intellectual capital.

Intellectual capital or intangible assets is often defined as intellectual capital or intangible assets do not have physical form. According to some experts, intellectual capital and intangible assets are interchangeable and frequently replace each other (Bukh et al., 2005). Intellectual capital includes knowledge, information, intellectual property rights, and expertise, all of which may be used to produce revenue (Stewart, 2012). (Pulic, n.d.) proposed indirect recognition of intellectual capital using a method for calculating the efficiency of value created as a result of the company's intellectual capability (Value Added Intellectual Coeficient - VAIC ${ }^{T M}$ ). The primary components of VAIC ${ }^{\mathrm{TM}}$ are revealed by the firm's resources, which include physical capital, human capital, and structural capital. VAIC ${ }^{\text {TM }}$ is derived by adding CEE (capital employed efficiency coefficient), HCE (human capital efficiency coefficient), and SCE (structural capital efficiency coefficient). The higher the value of VAIC ${ }^{\mathrm{TM}}$, the better the management of the company's potential value generation.

(Vishnu \& Gupta, 2014) model using the Value Added Intellectual Coeffient of (Pulic, n.d.) showed that there is a positive relationship between intellectual capital and corporate performance. Effective management of intellectual capital is the manager that has resulted in positive performance (Sharabati et al., 2010). The same results are also shown in the research by (Bollen et al., 2005) who conducted the analysis on managers of a pharmaceutical company in germany. According to the findings of the study, the components of intellectual capital have a beneficial impact on the company's success. In an environment of India, a study by (Pal \& Soriya, 2012) and (Ghosh \& Mondal, 2009) has provided a convincing result, i.e. there 
is a positive relationship between intellectual capital and profitability (ROA). (Ulum, 2007) performed a study on the impact of intellectual capital on the financial performance of Indonesian banks for three period, 2004-2006. The outcomes of this study suggest that intellectual capital (VAIC ${ }^{\mathrm{TM}}$ ) has a beneficial effect on the financial success of the firm. Therefore, the fourth hypothesis is developed as follows:

$\mathrm{H}_{4}$ : Intellectual capital has a significant influence towards financial performance.

Based on the phenomenon and the research is inconsistent, then the researcher is motivated to do more research about Corporate govenance and intellectual capital on the performance of a company that devoted in state-owned enterprises in Indonesia. The declining financial performance of the company-the state-owned company in Indonesia due to the weakening of the level of scrutiny and corporate goverance less well applied.

\section{METHOD}

A quantitative research methodology was used in this research. The population for this study includes state-owned enterprises registered with the Ministry of SOEs between 2016 and 2019, with sample methods based on Purposive Sampling and a set of criteria. The data gathered by determining state-owned firms that release annual reports for the fiscal year ended December 31, respectively, the financial statements of state-owned businesses are accessible, and the needed data is complete throughout the observation period. The data in this study was analyzed utilizing descriptive statistical tests, classic assumption tests, and hypothesis testing with multiple regression analysis. The aim of this analysis is to determine the strength and direction of the relationship between the independent and dependent variables. Data analysis approaches included multiple linear regression analysis with SPSS ver.25.

1. Operational Definition and Variable Measurement
a. Financial Performance
In this study, financial performance was assessed using

Return On Asset (ROA) as Brigham and Houston did (2006) with the following formula:

$$
R O A=\frac{\text { Net Income }}{\text { Total Asset }} \times 100 \%
$$

b. Corporate Governance

$$
\begin{aligned}
& \text { a) Independent Board of } \\
& \text { Commissioners } \\
& \text { A company's independent } \\
& \text { board of commissioners is } \\
& \text { calculated using the following } \\
& \text { formula: }
\end{aligned}
$$

In. Com $=\frac{\text { Number of Independent Commissioners }}{\text { Total Board of Commissioners }}$

b) Audit committee

The number of audit committee members in the firms determines the size of the audit committee. Formula for operationalize audit committee is as follows:

audit committee $\mathrm{it}_{\mathrm{t}}=$ number of members of audit

$$
\text { committee }
$$

c) Institutional Ownership

According to the following formula, institutional ownership in this study is measured as a percentage of institutional ownership in a firm:

Institutional Ownership $=\frac{\text { Total Institutional Shareholding }}{\text { Number of shares outstanding }}$

\section{c. Intellectual Capital}

Using value added models drawn from physical capital (VACA), human capital (VAHU), as well as structural capital (STVA), this study quantifies intellectual capital (VAIC ${ }^{\text {TM}}$ ) developed by (Pulic, n.d.). The term VAIC $^{\mathrm{TM}}$ represents the combination of the three additional values. The VAIC $^{\text {TM }}$ calculating formula is as follows:

$$
\text { VA }=\text { OUT }- \text { IN }
$$

information:

Output (OUT) : : Total sales and other revenue

Input (IN) : : Expenses and costs (other thar employee expenses)

Value Added (VA) : The difference between Outpul and Input 
Value Added Capital Employed (VACA) - Ratio of VA to CE. This percentage illustrates each CE unit's contribution to value-added organizations:

$$
\mathrm{VACA}=\mathrm{VA} / \mathrm{CE}
$$

information:

Human Capital (HC) : Employee expenses.

Capital Employed (CE) : Available funds (equ net income)

Structural Capital (SC) : VA - HC

Value Added Human Capital (VAHU) - Ratio of VA to HC. This ratio depicts the value added organization's contribution to each rupiah invested in $\mathrm{HC}$ :

$$
\mathrm{VAHU}=\mathrm{VA} / \mathrm{HC}
$$

Structural Capital Value Added (STVA) - Ratio of SC to VA. This ratio calculates the amount of $\mathrm{SC}$ required to create one rupiah from the VA and shows how effective SC is in creating value:

$$
\text { STVA }=\text { SC } / \text { A }
$$

Value Added Intellectual Coefficient $\left(\right.$ VAIC $\left.^{\mathrm{TM}}\right)$ - Indicates the intellectual capabilities of the organization. BPI is another name for VAIC ${ }^{\text {TM }}$ (Business Performance Indicator). information:

$$
\mathrm{VAIC}^{\mathrm{TM}}=\mathrm{VACA}+\mathrm{VAHU}+\text { STVA }
$$

VAIC $^{\text {TM }}$ : Value Added Intellectual Capital

VACA : Value Added Capital Coefficient

VAHU : Value Added Human Capital

STVA : Value Added Structural Capital

\section{d. Company Size}

Using the natural logarithm of total assets, the size of the firm was calculated in this study according to (Aziz \& Yuyetta, 2017) and (Seng \& $\mathrm{Su}, 2010$ ), with the following formula:

e. Leverage

$$
\text { SIZE }=\text { Ln (Total Assets) }
$$

The leverage variables in this study were measured using debt to equity ratio. The ratio used to measure this variable is the same as the ratio used in research conducted by (Aziz \& Yuyetta, 2017) and (Manihuruk \& Farahmita, 2015) with the following formula formulations:

$$
\text { Debt to Equity Ratio }=\frac{\text { Total Liabilities }}{\text { Total Equity }}
$$

\begin{tabular}{|c|c|c|c|c|c|}
\hline \multicolumn{6}{|c|}{ Descriptive Statistics } \\
\hline & $\mathbf{N}$ & Min & Max & Mean & Std. Dev \\
\hline Financial Performance & 164 & -0.0470 & 0,2207 & 0.0658 & 0,4083 \\
\hline Independen Commissioner & 164 & 0.0000 & 0,7273 & 0,2670 & 0,1772 \\
\hline Audit Committee & 164 & 2 & 6 & 3,57 & 1,034 \\
\hline Institutional Ownership & 164 & 66,9400 & 100,0000 & 97,6244 & 0,0670 \\
\hline Intellectual Capital & 164 & $-8,2046$ & 25,1424 & 3,5901 & 3,3123 \\
\hline Size & 164 & 25,8700 & 34,9994 & 30,5731 & 2,1194 \\
\hline Leverage & 164 & 0,0578 & 7,2600 & 1,7174 & 1,5335 \\
\hline
\end{tabular}

\section{f. Regression Model}

$$
\begin{aligned}
& \mathrm{FP}_{\mathrm{it}}=\alpha+\beta 1 \text {.In.Comit }+\beta 2 . \mathrm{CC}_{\mathrm{it}}+ \\
& \beta 3.1 O_{i t}+\beta 4.1 C_{i t}+\beta 5 \text {.Size } i t+ \\
& \beta 6 . L e v_{i t} \\
& \text { information: } \\
& \text { FP : Financial } \\
& \text { Performance } \\
& \text { In.com : Independent } \\
& \text { Commissioner } \\
& \text { AC : Audit committee } \\
& \text { IO : Institutional } \\
& \text { Ownership : : Intellectual } \\
& \text { Capital } \\
& \text { Size : Company size } \\
& \text { Lev : Leverage }
\end{aligned}
$$

Descriptive Statistical Analysis

Table 1

Descriptive Statistical Analysis

Source: SPSS ver. 25 
Table 2

Regression Model Test Results

\begin{tabular}{llccccc}
\hline \multirow{2}{*}{ Model } & \multicolumn{2}{c}{$\begin{array}{c}\text { Unstandardized } \\
\text { Coefficients }\end{array}$} & \multicolumn{2}{c}{$\begin{array}{c}\text { Standardized } \\
\text { Coefficient }\end{array}$} & \multirow{2}{*}{ Sig } \\
\cline { 2 - 5 } & \multicolumn{1}{c}{ B } & Std Error & Beta & \multicolumn{1}{c}{ T } & \\
\hline 1 (Constan) &, 037 &, 075 & &, 497 &, 620 \\
& Independen Commissioner &,- 036 &, 018 & -155 & $-1,986$ &, 049 \\
& Audit Committee &, 006 &, 004 &, 159 & 1,731 &, 085 \\
& Institutional Ownership &, 002 &, 001 &, 258 & 3,814 &, 000 \\
& Intellectual Capital &, 004 &, 001 &, 286 & 4,107 &, 000 \\
& Size &,- 006 &, 002 &,- 323 & $-3,282$ &, 001 \\
$\quad$ Leverage &,- 006 &, 002 &,- 214 & $-2,837$ &, 005 \\
Durbin-Watson & 1,401 & & & & \\
Adj R2 &, 304 & & & & \\
\hline
\end{tabular}

Source: SPSS ver. 25

Based on the table. 2 regression test above, then obtained multiple regression equations as follows:

$\mathrm{FP}=0.037-0.036 \mathrm{In} \cdot \mathrm{Com}+0.006 \mathrm{AC}$ +0.002 IO +0.004 IC -0.006 Size 0.006 LEV $+\mathrm{e}$

\section{RESULTS AND DISCUSSION}

\section{A. The Influence of Institutional Ownership on Financial Performance}

Financial Performance was positively affected by Institutional Ownership according to the results of a hypothesis test, meaning that Hypothesis 1 was accepted. Institutional parties are professionals who have more effective capabilities to control the company and control the actions of managers (Petta \& Tarigan, 2017). The larger proportion of shareholdings by institutions allows institutions, such as companies or business entities from outside the company to control the actions of managers, so that managers do not act in their own interests, and so that managers and institutional shareholders can work together to improve the company's financial performance (Arifani, 2012). If the institutional party has a large enough stake in the company, then the institutional party will have an incentive to supervise the performance of management and has the right to influence decisions and actions taken by management (Petta \& Tarigan, 2017).

The results of this study are also in line with research by (Sakawa \& Watanabel, 2020), which states that the institution's financial performance is stabilized by institutional shareholders. Institutional shareholders help to improve a company's performance, especially in firms with significant development potential. This suggests that institutional investors are more successful at monitoring firms with high growth predictions, resulting in better future profitability.

B. The Influence of Independent Commissioner on Financial Performance

Hypothesis testing for independent commissioner variable on Financial Performance revealed that independent commissioners had a substantial negative effect on Financial Performance, implying that Hypothesis 2 is accepted.

The independent commissioner indicated that there is an effort to minimize conflicts of interest within the company so that the level of transparency of company information will be higher. A company's board of commissioners must include at least 30 percent of its commissioners who are independent, according to the Financial Services Authority's (POJK) Regulation Number 33/POJK.04/2014 concerning Issuers and Public Companies' Boards of Directors and Commissioners. 
Independent commissioners also have a supervisory function in the company in order to create good corporate governance. More independent board members mean that board decisions will place the company's interests above their own, resulting in a negative impact on the company's performance (Arifani, 2012).

According to the findings of this study, the more the number of commissioners in a firm, the poorer the financial performance. This can be because the supervision carried out by the independent commissioners on management performance has not been maximized, while the company should continue to incurring expenses to pay independent commissioners, therefore profits become lower. Thus, the increasing number of independent commissioners will actually decrease the company's financial performance. The results of this study are in line with research by (Fadillah, 2017) which stated that an increase in the size of the independent board of commissioners would have a detrimental impact on the company's financial performance.

C. The Influence of Audit Committee on Financial Performance

One of the audit committee's responsibilities is to help the board of commissioners in overseeing the operation of the company. It also has several other responsibilities, such as reviewing all financial statements to ensure its quality, studying accounting policies, evaluating the effectiveness and level of compliance with internal controls, evaluating the possibility for fraud, and evaluating management policies that are considered to have a significant impact on financial statements (Arifani, 2012). According to POJK Number 55/POJK.04/2015 regarding the Establishment and Implementation Guidelines of the Audit Committee, companies must create an audit committee composed of at least three members selected from independent commissioners and parties outside of the business.

Although the average company sampled in this study has met the applicable provisions by having a minimum of 3 audit committees, the number has no significant effect on the company's financial performance. The reason is the appointment of an audit committee in the company is solely based on formal requirements and not based on the needs of the company, so it can have an impact on the quality of the audit committee appointed, such as appointing an audit committee with no accounting and financial background or no experience as an audit committee, and so forth. Because of this, audit committee responsibilities may not be carried out as efficient as they might be and the number of audit committees inside the company will have smaller impact on financial performance. Thus, hypothesis 2 was rejected. The results of this study are in line with the results of (Sembiring \& Saragih, 2019) and (Rahmawati et al., 2017) research which explains that the audit committee has no impact on the company's financial performance.

D. The The Influence of Intellectual Capital on Financial Performance

The results of this study indicate that the more effective the intellectual capital managed by the company, the company's financial performance will improve as well. The capital employed that is managed by the company, such as the addition of physical assets in the form of buildings to carry out business expansion, can improve the financial performance of the firm. This is because the capital used by the company to fund operating activities is solely aimed at achieving higher profitability. When a firm uses human capital in the form of human resources, such as education, experience, and skill sets, as well as innovation and creativity, it may improve its financial performance. Due to the fact that human resources inside a firm are the most significant party in implementing daily operational activities of a company's financial performance will be affected by the management of human resources with excellent quality, effectiveness, and efficiency. In addition, the larger and more effective the structural capital managed by the 
company, such as the production process, the use of information technology, customer relations, etc., will have an impact on improving the company's financial performance. This is because the allocation of large structural capital can be directed to invest in education and training of human resources in utilizing the structural capital used so as to improve the company's financial performance (Harianja \& Fauzie, 2014).

The results of this study are in line with research conducted by (Vishnu \& Gupta, 2014), (Thaib, 2013), and (Pal \& Soriya, 2012) which asserts that intellectual capital, as measured by the added value of capital employed, human capital, and structural capital, has a considerable beneficial influence on financial performance.

\section{CONCLUSION}

This research was conducted to test how corporate governance and intellectual capital could affect company's financial performance. The findings of this study revealed that corporate governance, as represented by independent commissioners, audit committees, and institutional ownership, as well as intellectual capital, could only influence financial performance by $30.4 \%$, while the remaining $69.6 \%$ was influenced by other variables not examined in this study. According to the findings of this study, institutional ownership and intellectual capital have a favorable influence on financial performance, but independent commissioners have a substantial negative effect on financial performance and the audit committee has no effect on financial performance.

This research contributes to some practical recommendations for state-owned enterprises in order to pay greater attention to to efficiently exploiting the company's intellectual resources so that the company's competitiveness, which is evaluated using financial performance, may be enhanced. Furthermore, efforts must be made to improve the functions of independent commissioners and audit committees in the context of monitoring director performance and financial reporting, so that the company's financial performance may be reported to shareholders in a transparent and responsible way. Based on the above conclusions, for further research can add managerial ownership variables, board of directors and board of commissioners, using other research models such as adding intervening variables, moderation or other controlling variables such as profitability and age of the company so as to increase the variety in research, expanding the research observation period because a longer research period will provide greater possibilities to improve results that are closer to the actual condition.

\section{REFERENCES}

arifani, R. (2012). Pengaruh Good Corporate Governance Terhadap Kinerja Keuangan Perusahaan (Studi Pada Perusahaan Yang Tercatat Di Bursa Efek Indonesia). Jurnal IImiah Mahasiswa Feb, 1(2).Googler Scholar

Ashari, S., \& Krismiaji, K. (2020). Audit Committee Characteristics And Financial Performance: Indonesian Evidence. Equity, 22(2), 139. Googler Scholar

Aziz, N. A., \& Yuyetta, E. N. . (2017). Analisis Faktor-Faktor Yang Mendorong Perusahaan. Diponegoro Journal Of Accounting, 6(4), 1-11. Googler Scholar

Bollen, L., Vergauwen, P., \& Schnieders, S. (2005). Linking Intellectual Capital And Intellectual Property To Company Performance. Management Decision, 43(9), 1161-1185. Googler Scholar

Bukh, P. N., Nielsen, C., Gormsen, P., \& Mouritsen, J. (2005). Disclosure Of Information On Intellectual Capital In Danish Ipo Prospectuses. Accounting, Auditing \& Accountability Journal. Googler Scholar

Elyasiani, E., \& Jia, J. (2010). Distribution Of Institutional Ownership And Corporate Firm Performance. Journal Of Banking And Finance, 34(3), 606620. Googler Scholar 
Fadillah, A. R. (2017). Analisis Pengaruh Dewan Komisaris Independen, Kepemilikan Manajerial Dan Kepemilikan Institusional Terhadap Kinerja Perusahaan Yang Terdaftar Di Lq45. Jurnal Akuntansi, 12(1), 37-52. Googler Scholar

Fuzi, S. F. S., Halim, S. A. A., \& Julizaerma, M. K. (2016). Board Independence And Firm Performance. Procedia Economics And Finance, 37(16), 460465. Googler Scholar

Ghosh, S., \& Mondal, A. (2009). Indian Software And Pharmaceutical Sector Ic And Financial Performance. Journal Of Intellectual Capital. Googler Scholar

Governance, K. N. K. (2006). Pedoman Umum Good Corporate Governance Indonesia. Knkg. Googler Scholar

Harianja, H., \& Fauzie, S. (2014). Analisis Value Added Sebagai Indikator Intellectual Capital Terhadap Kinerja Perbankan Di Indonesia. Jurnal Ekonomi Dan Keuangan, 2(5), 265281. Googler Scholar

Indonesia, I. A. (2012). Standar Akuntansi Keuangan, Penerbit Salemba Empat. Jakarta. Googler Scholar

Januarti, I. (2009). Analisis Pengaruh Faktor Perusahaan, Kualitas Auditor , Kepemilikan Perusahaan Terhadap Penerimaan Opini Audit Going Concern ( Perusahaan Manufaktur Yang Terdaftar Di Bursa Efek Indonesia ). Simposium Nasional Akuntansi 12 (Sna 12), 1-26. Googler Scholar

Lin, Y. R., \& Fu, X. M. (2017). Does Institutional Ownership Influence Firm Performance? Evidence From China. International Review of Economics And Finance, 49(March 2016), 17-57. Googler Scholar

Malik, Q. A., Hussain, S., Ullah, N., Waheed, A., Naeem, M., \& Mansoor,
M. (2021). Simultaneous Equations And Endogeneity In Corporate Finance: The Linkage Between Institutional Ownership And Corporate Financial Performance. Journal of Asian Finance, Economics And Business, 8(3), 69-77. Googler Scholar

Manihuruk, T. N. H., \& Farahmita, A. (2015). Analisis Faktor-Faktor Yang Mempengaruhi Pemilihan Metode Revaluasi Aset Tetap Pada Perusahaan Yang Terdaftar Di Bursa Saham Beberapa Negara Asean. Fakultas Ekonomika Dan Bisnis, Universitas Indonesia. Googler Scholar

Noorizkie, G., \& Siti, M. (2013). Pengaruh Mekanisme Corporate Governance Terhadap Kinerja Keuangan Perusahaan (Studi Empiris Pada Perusahaan Manufaktur Yang Terdaftar Di Bursa Efek Indonesia). Fakultas Ekonomika Dan Bisnis. Googler Scholar

Ojeka, S. A., Iyoha, S. O., \& Obigbemi, I. F. (2014). Effectiveness Of Audit Committee And Firm Financial Performance In Nigeria: An Empirical Analysis. Journal Of Accounting And Auditing: Research \& Practice, 2014. Googler Scholar

Pal, K., \& Soriya, S. (2012). Ic Performance Of Indian Pharmaceutical And Textile Industry. Journal of Intellectual Capital. Googler Scholar

Petta, B. C., \& Tarigan, J. (2017). Pengaruh Kepemilikan Institusional Terhadap Kinerja Keuangan Melalui Struktur Modal Sebagai Variabel Intervening Pada Perusahaan Manufaktur Yang Terdaftar Dalam Bursa Efek Indonesia (Bei). Business Accounting Review, 5(2), 625-636. Googler Scholar

Psak No. 19 Tentang Aktiva Tidak Berwujud., (2000). Googler Scholar

Pulic, A. (N.D.). Basic Information On Victim. Jurnal Dinamika Akuntansi, 5(2), 172-182. Googler Scholar 
Rahmawati, I. A., Rikumahu, B., \& Dillak, V. J. (2017). Pengaruh Dewan Direksi, Dewan Komisaris, Komite Audit Dan Corporate Social Responsibility Terhadap Kinerja Keuangan Perusahaan. Jurnal Akuntansi Dan Ekonomi, 2(2), 54-70. Googler Scholar

Sakawa, H., \& Watanabel, N. (2020). Institutional Ownership And Firm Performance Under StakeholderOriented Corporate Governance. Sustainability, 12(3), 1-21. Googler Scholar

Sembiring, Y. C. B., \& Saragih, A. E. (2019). Pengaruh Komisaris Independen Dan Komite Audit Terhadap Kinerja Keuangan Pada Perusahaan Perbankan Yang Terdaftar Di Bursa Efek Indonesia. Jurnal Riset Akuntansi Dan Keuangan, 5(2), 229-242. Googler Scholar

Seng, D., \& Su, J. (2010). Managerial Incentives Behind Fixed Asset Revaluations: Evidence From New Zealand Firms. International Journal Ofbusiness Research, Department of Accountancy And Business Law, Working Paper Series, 3. Googler Scholar

Sharabati, A. A., Naji Jawad, S., \& Bontis, N. (2010). Intellectual Capital And Business Performance In The
Pharmaceutical Sector Of Jordan. Management Decision, 48(1), 105131. Googler Scholar

Stewart Thomas. (2012). Modal Intelektual/Intellectual Capital. Pt. Gramedia. Googler Scholar

Thaib, F. (2013). Value Added Intellectual Capital (Vahu, Vaca, Stva) Pengaruhnya Terhadap Kinerja Keuangan Bank Pemerintah Periode 2007 - 2011. Jurnal Emba: Jurnal Riset Ekonomi, Manajemen, Bisnis Dan Akuntansi, 1(3), 151-159. Googler Scholar

Ulum, I. (2007). Pengaruh Intellectual Capital Terhadap Kinerja Keuangan Perusahaan Perbankan Di Indonesia. Program Pascasarjana Universitas Diponegoro. Googler Scholar

Vishnu, S., \& Gupta, V. K. (2014). Intellectual Capital And Performance Of Pharmaceutical Firms In India. Journal Of Intellectual Capital. Googler Scholar

Zulfikar, R., Lukviarman, N., Suhardjanto, D., \& Agustiningsih, S. W. (2017). Competition , Independent Commissioner, Risk Disclosure And Financial Performance. Review of Integrative Business And Economics Research, 6(1), 76-91. Googler Scholar

\section{Copyright holder:}

Husnah Nur Laela Ermaya, Ayunita Ajengtiyas Saputri Mashuri (2021)

First publication right:

Journal of Social Science

This article is licensed under:

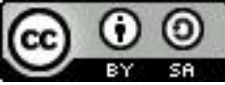

